\title{
The availability of feeds for livestock: Competition with human consumption in present world
}

\author{
H. Steinfeld ${ }^{\dagger}$ and C. Opio \\ Animal Production and Health Division, Food and Agriculture Organization, Rome, Italy
}

Rising costs of grain for food and feed and the increasing demand for animal protein have intensified the debate on the use of food-grain for the production of high value animal protein. Demand for feed concentrates, particularly pronounced in developing countries, has been growing steadily over the past decades largely driven by the increasing demand for meat and milk products. Presently, the livestock sector uses about 740 million tonnes of cereals, representing about one-third of the global cereal harvest. The transition from land-based extensive ruminant systems to large-scale industrial non-ruminant systems that rely on concentrate feed has been enabled by a surplus of grain as a consequence of improvements in crop productivity, resulting into low global cereal prices. Recent price spikes have not altered this picture fundamentally, even though many observers expect higher and more volatile cereal prices in future.

The last two decades have however witnessed a slow down in the demand growth for feed by the livestock sector. Between the period 1980 and 2007, while meat production increased at a rate of $2.7 \%$ per annum, concentrate feed demand grew at about $1.3 \%$ per annum.

The food-feed competition has occurred through an adjustment of prices driven by a decline in output or surge in demand for livestock products. The competition for grain has largely been based on the changes in dietary patterns which have occurred along with income growth. As per capita income changes, populations tend to change their diets to include more animal-based products. Increased demand for animal protein indirectly increases demand for grain driving grain prices higher. Increases in grain prices may affect the poor consumers whose diets are made up of a larger proportion of grains compared to diets of an expanding urban middle-class. Closely linked with demand for animal feed is the displacement of production of crops with that of feed-crops - a trend particularly predominate in Latin America.

Another dimension of the competition for grains is the linkage between the food-feed markets during periods of shortfall. The livestock sector plays a crucial 'cushioning' role by adjusting to changes in supply and hence maintaining food consumption in the case of supply shortfalls. As demonstrated in the recent food crisis 2006-2008, during occasional supply shortfalls, the sector's has played an important role in adjusting its demand manifested through the reduction in feed-grain demand releasing grain supply for direct use as food or replacement of grain with other alternative feedstuffs.

Recent trends have however added a new facet to the food-feed competition. Today, forces external to grain markets and the sphere of the dynamics of changing consumption patterns such as rising oil prices and the diversion of grain to bio-energy production are increasingly playing a key role in shaping the food-feed competition. A key question for the global food and agriculture system is therefore how the continued demand for animal source foods can be accommodated in a world with finite land, water and other natural resources.

${ }^{\dagger}$ E-mail: Henning.Steinfeld@fao.org

doi:10.1017/S204047001000049X

\section{Nutritional and energy values of tropical foliages in pigs}

\author{
Carole Régnier, B. Bocage, H. Archimède and D. Renaudeau ${ }^{\dagger}$
}

INRA UR143, 97170 Petit Bourg, Guadeloupe, French West Indies

Introduction

In tropical areas, a rational exploitation of local breeds and local feed resources would increase the sustainability of production systems. In the context of livestock production from local resources in an integrated farming system, tropical foliages could be an interesting source of protein (Bui Huy Nhu et al., 2000; Preston and Rodriguez, 2004). However, additional knowledge is required to determine how these local feed resources are used by animals. This work aimed to determine the nutritive and energy value of four tropical foliages (cassava, sweet potatoes, erythrina and cocoyam) in the local Caribbean pig breed (Créole pig).

${ }^{\dagger}$ E-mail: david.renaudeau@antilles.inra.fr 


\section{Advances in Animal Biosciences}

\section{Material and methods}

The effect of feeding different tropical foliages was tested on digestive utilization of nutrients and energy, and on rate of passage of digesta measured using a pulse dose of ytterbium oxide. A total of 9 castrated male Creole pigs with an average initial body weight of $35 \mathrm{~kg}$ were used in three $3 \times 3$ Latin-Square design. All the tropical foliages were sun dried at $50^{\circ} \mathrm{C}$ for 2 to 3 days and ground before the experiment. Seven experimental diets differing in botanical origin and fraction of foliage (leaves or leaves + stems) were studied (Table 1): a control corn and soybean meal diet (diet C) and six experimental diets in which $20 \%$ of the diet $C$ was replaced by cassava leaves (diet $C A_{L}$ ), cassava leaves + stems (diet $C A_{L}+s$ ), sweet potatoes leaves (diet $\left.S P_{L}\right)$, sweet potatoes leaves + stems (diet $S P_{L}+s$ ), cocoyam leaves $\left(\operatorname{diet} C \mathrm{CO}_{L}\right.$ ) and erythrina leaves (diet $E R_{L}$ ).

Table 1 Chemical composition and gross energy content of the tropical foliages and the control diet

\begin{tabular}{|c|c|c|c|c|c|c|c|}
\hline & $\mathrm{C}$ & $C A_{L}$ & $C A_{L+S}$ & $S P_{L}$ & $S P_{L+S}$ & $\mathrm{ER}_{\mathrm{L}}$ & $\mathrm{CO}_{\mathrm{L}}$ \\
\hline Dry matter, \% & 86.9 & 86.8 & 82.6 & 84.0 & 86.1 & 90.5 & 87.4 \\
\hline \multicolumn{8}{|l|}{ Chemical composition, \% DM } \\
\hline Organic matter & 93.8 & 90.1 & 90.2 & 85.8 & 83.4 & 90.0 & 84.6 \\
\hline Crude protein & 18.1 & 29.7 & 30.4 & 20.6 & 18.7 & 29.1 & 16.8 \\
\hline Starch & 42.5 & 0.9 & 0.3 & 1.2 & 1.7 & 0.9 & 3.1 \\
\hline Neutral detergent fibre & 15.8 & 51.2 & 61.5 & 36.8 & 44.9 & 47.7 & 32.5 \\
\hline Acid detergent fibre & 4.4 & 36.7 & 42.8 & 25.9 & 32.7 & 28.8 & 25.3 \\
\hline Gross energy, MJ/kg DM & 18.2 & 20.6 & 19.7 & 17.7 & 16.9 & 19.6 & 17.9 \\
\hline \multicolumn{8}{|l|}{ Digestibility coefficient, \% } \\
\hline Crude protein & 84.8 & 8.6 & 14.2 & 21.3 & 20.8 & -35.3 & 53.9 \\
\hline Energy & 85.7 & 31.0 & 31.2 & 38.3 & 47.8 & 25.3 & 46.9 \\
\hline \multicolumn{8}{|l|}{ Rate of passage parameters* } \\
\hline Relative to $\mathrm{Yb}$ incorporated, \% & 85.7 & 87.4 & 90.8 & 71.4 & 58.2 & 94.8 & 89.1 \\
\hline MRT, h & 41.1 & 23.3 & 20.3 & 29.1 & 37.3 & 34.5 & 35.6 \\
\hline
\end{tabular}

*Results on the total diet (control + leaves or leaves and stems).

\section{Results and Discussion}

When compared to the control diet, the inclusion of foliages reduced the digestibility of energy (from 6 to $11 \%$ depending on the botanical origin). This decrease was partly related to a reduction of the mean retention time $\left(41.1 \mathrm{~h}\right.$ for the diet $\mathrm{C}, 34 \mathrm{~h}$ on average for $\mathrm{SP}_{\mathrm{L}}, \mathrm{SP}_{\mathrm{L}}+\mathrm{S}_{l} \mathrm{CO}_{\mathrm{L}}$ and $E R_{L}$ diets, and $23 \mathrm{~h}$ on average for the $C A_{L}$ and $C A_{L+s}$ diets). The apparent digestibility coefficients of tropical foliages were determined according to difference methods (Table 1). In the present study, less than $30 \%$ of the proteins were digested in the total tract. Leterme et al. (2005) and Bui Huy Nhu et al. (2000) report higher values for protein cocoyam and cassava leaf meal (46-57\%). The leaf meals used in the present experiment had lower protein content than cocoyam and cassava leaf meal and this could have affected the $\mathrm{N}$ digestibility. Energy digestible coefficient of foliage was lower than Control coefficient (average 36.3 vs. $85.7 \%$ ). Energy digestible content of foliage was rather low and differed according to the botanical origin of the foliage with a higher value for $\mathrm{CO}_{\mathrm{L}}(8.4 \mathrm{MJ} / \mathrm{kg} \mathrm{DM})$ and a lower value for $\mathrm{CA}_{\mathrm{L}} \mathrm{s}$ (6.4 MJ/kg DM), with intermediate value for $\mathrm{SP}_{\mathrm{L}}, \mathrm{SP}_{\mathrm{L}}+\mathrm{s}$ and $E R_{\mathrm{L}}(7.2 \mathrm{MJ} / \mathrm{kg} \mathrm{DM})$. For cassava and sweet potatoes, the inclusion of stems to the leaves did not significantly affect the energy digestibility $(P>0.05)$.

\section{Conclusion}

This study shows that the main limiting factor of tropical foliage is their high crude fibre content which negatively affects the energy and crude protein digestibility in growing pigs. Some other secondary components (tannins) could also impact on digestibility. Despite their nutritional limits, tropical foliages offer an interesting source of proteins (177-204 g/kg of DM), sometimes with good essential amino acid content and could partly replace soybean meal in pig feeding especially in small scale farming systems. For that, the determination of the amount of digestible amino acids is required to calculate the true nutritional value of the crude protein provided by tropical foliages.

\section{References}

Bui Huy Nhu P, Ogle B and Lindberg JE 2000. Effect of replacing soybean protein with cassava leaf protein in cassava root meal based diets for growing pigs on digestibility and $\mathrm{N}$ retention. Animal Feed Science and Technology 83, 223-235.

Leterme P, Londono AM, Estrada F, Souffrant WB and Buldgen A 2005. Chemical composition, nutritive value and voluntary intake of tropical tree foliage and cocoyam in pigs. Journal of the Science of Food and Agriculture 85, 1725-1732.

Preston TR and Rodriguez L 2004. Production and utilization of cassava foliage for livestock in integrated farming systems. Livestock Research for Rural Development 16 , article 28. 